\title{
Selenium soil mapping under native Brazil nut forests in Brazilian Amazon
}

\author{
K.D. Batista* \\ Researcher at Embrapa Roraima, Boa Vista, Roraima, Brazil \\ *E-mail:karine.batista@embrapa.br \\ K.E. da Silva, Martins, G.C. \\ Researcher at Embrapa Amazônia Ocidental, Manaus, Amazonas, Brazil \\ L.H.O. Wadt \\ Researcher at Embrapa Rondônia, Porto Velho, Rondônia, Brazil
}

L.M. da Silva

Researcher at Embrapa Acre, Rio Branco, Acre, Brazil

N.J.M. Júnior, M.C.Guedes

Researcher at Embrapa Amapá, Macapá, Amapá, Brazil

R.C. de Oliveira Júnior

Researcher at Embrapa Amazônia Oriental, Belém, Pará, Brazil

C.A.S. Magalhães, A.B.B. Tardini

Researcher at Embrapa Agrossilvipastoril, Sinop, Mato Grosso, Brazil

\begin{abstract}
Brazil nut is distributed in Amazon and represents an important source of selenium, which plays an important role in the human diet. The Brazilian Agricultural Research Corporation, EMBRAPA, through the project "Brazil Nut Mapping and Environmental, Social and Economic Characterization of Production Systems in Amazon - MapCast" has been conducting studies in six Amazon States, aiming to increase knowledge about this species. Among the various research lines from the project, studies on selenium in the soil have been developed with a wide sampling spatial range. The results of this study are an important source of information that will subsidize studies on the relationship of Se with fruit production, as well as the association of this element in the soil with selenium content in nuts, contributing to identify areas with higher selenium levels and for food safety of nut human consumers.
\end{abstract}

\section{INTRODUCTION}

Brazil nut (Bertholletia excelsa Bonpl., Lechytidaceae family) is one of the symbol tree of the Amazon. It is an important non-timber forest product for human livelihoods in the Amazon region due to its social, ecological and economical importance (Wadt \& Kainer, 2009).

It is a dominant tree, which occupies the upper canopy of the forest, influencing the dynamics of gaps and forest succession. Nevertheless, the traditional harvesting system of nuts, in most producing areas, is still characterized by low technological level, due to changes in the level of social organization around this activity, to land tenure/use, and the diversity of production systems, which need to be better characterized. The variations in nuts productivity in different Amazon regions, due to biotic and abiotic relationship in their natural occurrence sites must be highlighted. These relations demand further studies for better understanding of biotic and abiotic relations and its influence on fruit production.

Another relevant aspect of Brazil nut is the high level of selenium (Se) in its nuts (Lemire et al, 2010; Parekh et al., 2008). The species has been considered an important source of Se (Gabos et al., 2014) and its concentration in nuts is highly variable, with values from 5 to $512 \mathrm{mg} . \mathrm{kg}^{-1}$ of Se (Dumont et al., 2006; Chang et al., 1995). Although there is a variation in Brazil nuts Se content, it is known that the ingestion of a single nut per day is enough to feed the human needs for the element (Thomson et al., 2008).

Se content in food usually dependends on Se content in soil (Gabos et al., 2014). In soil, the content of the element can be explained by the mineralogy (Winkel et al., 2012) or other soil attributes, as organic carbon (Perez-Roca et al., 2010), or by human activities (Gabos et al., 2014).

Because of the great importance of Brazil nut and the several unknowns about the species distribution in the Amazon, in 2013 Embrapa approved the pro- 
ject "Brazil Nut Mapping and Environmental, Social and Economic Characterization of Production Systems in Amazon (MapCast)", with actions aimed at generating database and methodologies for mapping and modeling native Brazil nut, characterize production factors and nut's production systems and also the social, environmental and economic factor that can affect the Brazil nut production.

Among the specific aims from MapCast, we cite the study of physical and chemical soil attributes, including Se evaluation in six different regions in Brazilian Amazon. So, to describe variations in Se soil levels, at the landscape scale is very important to understand the behavior of this element in the Amazon soils. Then it will be possible to correlate the results generated with Se content in nuts, greatly contributing to the enhancement of nuts production chain and greater food security for the human population.

Without knowing the different relations involved in the Brazil nut harvest, and population variations arised from the environmental diversity, there is no way to forward on the recommendations of practical management to each Amazon region. The multidisciplinarity aspect of the MapCast project will provide results that will support many other research activities. This integration is critical for generating positive impacts in the development of Brazil nut production chain.

\section{MATERIALS AND METHODS}

MapCast is led by Embrapa Amazônia Ocidental (Manaus-AM), with 59 members, composed by academics and researchers. Its research abrangency area comprises six Amazon States: Acre, Amapá, Amazonas, Mato Grosso, Pará and Roraima. The project started in 2014 and will extend through 2018, analizing about 776 soil samples in Amazon. Among its research lines, the Se study is related to the "Characterization and environment modeling of natural Brazil nut occurrence".

Soil samples were collected in a regular grid of 30 x $50 \mathrm{~m}$, at $0-20 \mathrm{~cm}$ depth, and also its spatial location using the UTM-WGS84 coordinate system. Then, they were brought to the laboratory for drying in the air forced circulation stove at $40^{\circ} \mathrm{C}$ and sieving in 2 $\mathrm{mm}$ mesh. After, the samples were sent to the Soil Analysis Laboratory of the Federal University of Lavras, Minas Gerais, for Se analysis.

Using geostatistics, regionalized maps will be built for Se variable, including accuracy measures of the resulting maps, when methodology allows. Thus, comparisons of changes in the levels of Se will be made among different sampled locations and correlation studies between fruit production and Se content. All statistical analyzes will be made in the $\mathrm{R}$ program (R Core Team, 2015).

\section{EXPECTED RESULTS}

Regionalized maps for Se will be made for each sampled location, showing the Se behavior in natural Brazil nut of Amazon soils. In the MapCast project, results will support additional studies of correlation between fruit yield and Se levels. It is expected from these results, to perform additional studies on Se content in Brazil nuts, with the same scope of this study, at the same comprehensiveness. Results will allow valuing this important non-timber forest product as well as the aspects related to food safety for human consumers.

\section{REFERENCE}

R Core Team .2012. R: A language and environment for statistical computing. $R$ Foundation for Statistical Computing, Vienna, Austria. ISBN 3-900051-07-0, URL:http://www.R-project.org/.

Chang, J.C. et al. 1995. Selenium content of brasil nuts from two geografic locations in Brasil. Chemosphere 30: 801802 .

Dumont, E. et al. 2006. Speciation of Se in Bertholletia excelsa (Brazil nut): A hard nut to crack? Food Chemistry 95: 684-692.

Gabos, M. B.; Alleoni, L. R. F.; Abreu, C. A. 2014. Background levels of selenium in some selected Brazilian tropical soils. Journal of Geochemical Exploration 145: 35-39.

Lemire, M., Fillion, M., Barbosa, F., Guimarães, J.R.D., Mergler, D., 2010. Elevated levels of selenium in the typical diet of Amazonian riverside populations. Sci. Total Environ. 408: 4076-4084.

Parekh, P.P., Khan, A.R., Torres, M.A., Kitto, M.E., 2008. Concentrations of selenium, barium, and radium in Brazil nuts. J. Food Compos. Anal. 21: 332-335.

Roca-Perez, L., Gil, C., Cervera, M.L., Gonzálvez, A., RamosMiras, J., Pons, V., Bech, V., Boluda, R., 2010. Selenium and heavy metals content in some Mediterranean soils. J. Geochem. Explor. 107: 110-116.

Thomson, C. D. et al. Brazil nuts: an effective way to improve selenium status. 2008. Am J Clin Nutr 87: 379-384.

Wadt, L. H. O; Kainer, K.A. 2009. Domesticação e melhoramento da castanheira. In: Borém, M. T. G. L.; Charles, R. C (Eds.) Domesticação e melhoramento: espécies amazônicas.Viçosa, MG.

Winkel, L.H.E., Johnson, C.A., Lenz, M., Grundl, T., Leupin, O.X., Amini,M., Charlet, L. 2012. Environmental selenium research: from microscopic processes to global understanding. Environ. Sci. Technol. 46: 571-579. 